CLINICAL HEMORHEOLOGY, Vol. 11, pp. 823-824, 1991

$0271-5198 / 91 \$ 3.00+.00$ Printed in the USA.

Copyright (c) 1992 Pergamon Press plc. All rights reserved.

\title{
CONTENTS OF BIORHEOLOGY, VOLUME 28, NUMBERS 3/4
}

A.L. Copley and A. Silberberg

E. Fukada

A.L. Copley

S. Oka

P. Brun, J. Malak, M.H. Bui, A.M. Duval and J. Ohayon

J.K. Gwathmey and R.J. Hajjar

H.E.D.J. ter Keurs, P.Ph. de Tombe,

P.H.M. Backx and T. Iwazumi

R.S. Chadwick

H.-Q. Chen, G.-H. Zhong, L. Li,

X.-Y. Wang, T. Zhou and Z.-Y. Chen

L. Weiss, J.P. Harlos

and G. Elkin

J. L. Cezeaux, V. Austin, M.C. Hosseinipour, K.A. Ward and S. Zimmer

N. Rudraiah, S.R. Kasiviswanathan and P.N. Kaloni

S.P. Sutera and D.J. Krogstad

G.B. Nash

Y.I. Cho and K.R. Kensey

M. Kaibara and Y. Kawamoto

M. Minamiyama and S. Hanai

B. Diebold, A. Delouche, E. Abergel,

$\mathrm{Ph}$. Delouche, Ph. Dumée and P. Péronneau
Contents

In Memory of Syoten Oka Biorheologist and Person

119 A Tribute to Syoten Oka

123 Obituary: Syoten Oka (1907-1990)

133 Oka's Theories Bearing on the Vessel-Blood Organ and its EEFL Interface

141 Excerpt from letter of 23 May 1990 to A.L. Copley

Proceedings of the Seventh International Congress of Biorheology, Nancy, France, 18-23 June 1989, Part V

Symposium: Cardiac Muscle Cell Rheology

143 A modelized distribution of actomyosin interactions in the vertebrate cardiac muscle

151 Protein kinase $\mathrm{C}$ activation in human ventricular myocardium

161 Rheology of myocardium. The relation between force, velocity, sarcomere length and activation in rat cardiac muscle

171 Prediction of the cardiac muscle force-velocity relation from its force-time and force-length relations

Papers

177 Effects of gender and age on thixotropic properties of whole blood from healthy adult properties
subjects

185 Measurements of compression of Ehrlich ascites tumor cells and their relevance to hematogenous metastasis

195 The effects of shear stress and metastatic phenotype on the detachment of transformed cells

207 Generalized dispersion in a synovial fluid of human joints

221 Reduction of the surface-volume ratio: A physical mechanism contributing to the loss of red cell deformability in malaria

231 Red cell mechanics: What changes are needed to adversely affect in vivo circulation

241 Effects of the non-Newtonian viscosity of blood on flows in a diseased arterial vessel. Part 1 : Steady flows

263 Rheological measurement of blood coagulation in vascular vessel model tube consisting of endothelial cells monolayer

275 Propagation properties of vasomotion at terminal arterioles and precapillaries in the rabbit mesentary

287 Influence of pulsatility on the development of intracardiac jets: An in vitro laser Doppler study

(Contents Continued) 
(Continuation of Contents)

K.A. Ward, W.-I. Li, S. Zimmer and and T. Davis

F.P. Miles and A.L. Nuttall

M. Singh, C.L. Lucas, G.W. Henry, J.I. Ferreiro and B.R. Wilcox

A. Silberberg
301 Viscoelastic properties of transformed cells: Role in tumor cell progression and metastasis formation

315 Microvessel diameter estimation: Error bias correction of serial measurements Brief Communication

333 Multiangle visualization of flow patterns in saccular aneurysms Book Review

341 Biomechanics, Motion, Flow, Stress and Growth by Y.C. Fung

343 Abstracts: Symposium on Biorheology, October 24-25, 1990, Sante Fe, New Mexico

351 Recommended Abbreviations and Units in Hematology

353 Contents of CLINICAL HEMORHEOLOGY Volume 10, Number 5 